Article

\title{
Pietas Austriaca? The Imperial Legacy in Interwar and Postwar Austria
}

\author{
Dieter A. Binder \\ Chair of Cultural Studies, Andrássy University, Pollack Mihály tér 3, 1088 Budapest, Hungary; \\ dieter.binder@uni-graz.at
}

Received: 7 July 2017; Accepted: 21 August 2017; Published: 29 August 2017

\begin{abstract}
This paper aims to outline the specific Habsburg character of Austrian Catholicism through a study of Pietas Austriaca, the supposed Habsburg tradition of Catholic piety, and its role in the First and Second Austrian Republics. It analyzes the narrative of Austrian history presented by the Heldendenkmal, or Heroes' Monument, which was erected in Vienna in 1934. Further, it argues that Pietas Austriaca was linked in the postwar period to a notion of Heimat (Home, Homeland) and served the needs of Austrian political Catholicism, which was seeking to recruit former National Socialists.
\end{abstract}

Keywords: Habsburg; Austria; empire; Catholicism; Pietas Austriaca; Christian Social Party; Austrian People's Party; Heimat; Heldendenkmal

Political Catholicism utilised its commitment to the concept of Pietas Austriaca to define its political position towards both Social Democratic Austro-Marxism and National Socialism. After 1945, the Roman Catholic Church served as a vehicle for the denazification of former National Socialists. By creating the "Heimat", it endeavoured to establish a common front against Social Democracy in order to implement a masked bourgeois bloc. Ultimately, this would to some extent explain the rise of the Austrian Freedom Party from 1986 on.

"The Pietas Austriaca, i.e., Austrian piety-referring here to Austria as Casa d'Austria, i.e., the House of Austria, and not as a geopolitical entity - was propagated in the Baroque era as the most fundamental virtue of the Habsburg dynasty. During the Reformation, the Habsburg dynasty remained uncompromisingly true to the Roman Catholic Church. Catholicism was the de facto state religion in the Habsburg realm. The foundation for a baroque Catholicism that would for many years shape the Habsburg territories was decisively laid by promoting pious endowments, pilgrimages and Marian veneration, but also by pursuing an intransigent and relentless religious policy" (Mutschlechner n.d.). After 1918, by contrast, Otto Bauer, the chief theorist of the Social Democrats, succinctly challenged the political position of the Church, asserting in his 1934 publication titled "Aufstand der österreichischen Arbeiter" (Insurrection of the Austrian Workers) that "in the long term, thirty percent cannot possibly exercise dictatorship over seventy percent of the people, the village will no longer rule the city and clericalism will cease to control two-thirds of the people who are non-clerical" (Bauer 1934). The pathetic Catholicism of Austro-Fascism, whose strategies of legitimisation also utilised the perception of religious tradition, interpreted "new Austria" as a bastion of Christianity against heathen National Socialism and atheist Austro-Marxism.

The concept of Pietas Austriaca thus shifted from Habsburg self-portrayal to the apodictic frame narrative of political Catholicism. As the parliamentary crisis set in at the end of the 1920s, the concept was militarised in the form of the paramilitary Ostmärkische Sturmscharen (Eastern March Stormtroopers), also known as Ölberghusaren (Mount Olivet Hussars) (Reich 2000). The Austrian Army, which was oriented towards the German Reichswehr in the 1920s, followed that development in the looming coup d'état of 1933/34. Ultimately, the pledge to Catholicism and cogitations on the imperial aspect of Pietas Austriaca aimed to serve political ends-e.g., the cult around Christian Social Chancellor 
Ignaz Seipel and Engelbert Dollfuss, the Austrofascist dictator who was assassinated in 1934 as part of a failed Nazi coup, with its building of churches and martyr narrative-within an increasingly secular environment, where reference to Catholic tradition would act as a substitute for conservative theoretical deficit. After 1945, it also paved the way for a somewhat more cautious political Catholicism campaigning for the votes of former National Socialists and to establish its position in the Cold War.

The political absolutism and economic restrictions of the First World War caused the peasant population and tradesmen - core followers of the Christian Social Party outside Vienna-to distance themselves from the Crown (Staudinger et al. 1995; Wohnout 2004). While at the beginning of October 1918, Viennese followers of the party had expressed their loyalty to Emperor Charles, provincial Austria was already beginning to turn to the Republic. Emperor Charles' proclamation to relinquish all participation in State administration enabled the Catholic hierarchy to return to business as usual. Staunchly committed to practical theology, the Prince-Archbishop of Vienna, Cardinal Piffl, who in mid-October had proclaimed "Gut und Blut für unseren Kaiser. Gut und Blut für unser Vaterland" (Blood and treasure for our Emperor/our Fatherland), now declared that "for the future election campaign", the catchphrase 'Monarchy or Republic' was to be principally postponed (Friedrich Gustav Cardinal Piffl 1992). Piffl's sudden switch reduced the self-staging strategy of the Habsburgs in terms of Pietas Austriaca to securing the "property of the Church", which he regarded as endangered by the secularism of the Social Democrats and German Nationalist circles. ${ }^{1}$

The Social Democrats' call for the separation of State and Church-a policy which they shared with the Liberals and German Nationalists-dates back to the Party's founding period and was programmatically defined at the 1888/89 Hainfeld Party Congress. Their main demands included the elimination of Church influence on the educational system and introduction of obligatory civil marriage. In the Church's view, these issues were exacerbated by insisting on the liberalisation of abortion and abolition of the Abortion Act, Section 144/Austrian Criminal Code (§ 144 StGB). The political Catholicism of the Christian Social Party, and to some extent its successor, the Austrian People's Party (Österreichische Volkspartei, ÖVP), adopted Church positions in those questions. A reasonable compromise reached in 1926 to reform the educational system was undermined in 1933/34 through a spell of dramatic re-confessionalisation, and civil marriage was introduced by the National Socialists in 1938, a solution that was finally accepted in 1945/46. As for the educational system and a possible reversion to the 1926 School Act, any proposals made by the Social Democratic movement to reform the educational system have, until the present day, triggered a Pavlovian response, mainly in Catholic lobbyist circles and in parts of the Austrian People's Party. The slightest hint of reform would cause them to categorically dig in their heels. On the other hand, after putting up their defences dutifully, the Austrian People's Party responded pragmatically, finally accepting the solution that was realised in Bruno Kreisky's penal law reform. The formation of a Catholic and German Nationalist procreation front during the 1975 anti-abortion referendum failed and was henceforth backed only by a minority.

While the democratically-minded peasantry pragmatically supported the reconstruction of the State in 1918/19, behind the scenes, Ignaz Seipel was already organising his Party along Catholic lines. In that respect, it is worth noting that the Party's primary and, to many, deeply irritating goal was to campaign for clerical income in the so-called 1920/21 Congrua portio debate. This issue led to the formation of a broad party front against the Social Democrats, although it did not serve any of the party clientele's principal interests. As far as the question of state income for clericals, the Congrua, was concerned, Seipel, under the pressure of the bishops, did not budge an inch. The basis for his position was what he believed to be the "primacy of the Church over Christian (Social) party politics" and "Pietas Austriaca" (Liebmann 2003).

In its political manifesto of December 1918, the Christian Social Party, in keeping with the Church hierarchy, advocated the protection of family and youth, emphasized the "preservation of national

1 For basic research on the position of the Catholic Church between 1918 and 1920, see (Binder 2008). 
customs and culture", committed themselves to "physical and moral health" and to dealing with the "declining birth rate, tuberculosis and sexually transmitted diseases", while at the same time appealing for a "struggle" against the "corruption and imperiousness of Jewish circles". Importantly, these were issues they had in common with German Nationalist parties. As regards concepts of social progress, social-democratic reforms were duly absorbed in order to make concessions to the Party's left wing. This, in turn, provided a specific basis for negotiations between the Christian Social and Social Democratic parties. However, the then more influential Austrian provincial wing within the Christian Social party came to an agreement with the coalition partner against the will of the Viennese wing on the prosecution of war crimes committed by officers, the abolition of peerage, as well as the expulsion and take-over of the assets of the House Habsburg-Lorraine (Binder 2008, pp. 247-49). By doing so, the party contributed its fair share to providing a pragmatic transition from Monarchy to Republic, thus permanently inhibiting any notable fundamental monarchist or legitimist opposition. In collaboration with the Catholic bishops, the party, in its manifesto, had now replaced the absent Emperor as guarantor of Pietas Austriaca by incorporating the bishops' anti-modernist positions and demands to safeguard their vested rights as quasi-ideological guidelines.

In 1945, that process seemed to repeat itself, despite the newly-founded Austrian People's Party ruling out the return of the Catholic hierarchy to political Catholicism—at least outwardly.

No doubt, among the political elites of Socialist politician Karl Renner's 1945 provisional government there existed an anti-National Socialist consensus that also embraced the commitment to an independent Austrian state. Some representatives of the Austrian People's Party met with Communist intellectuals such as Ernst Fischer to discuss the question of the "Austrian nation". While the Communists sought to pursue the positions they had developed in the course of the People's Front strategy in 1937, which Alfred Klahr had put to paper (Klahr 1937), the theorists of the People's Party, notably Alfred Missong, reverted to concepts (Missong 2006) that had already been subject to discussion in the 1920s (Winter et al. 1927) and which they had also introduced into the national discourse on the authoritative "corporate state" (Bruckmüller 1984). By 1947, the Austrian People's Party, initially under the influence of French leftist Catholicism, were seeing themselves-insofar as any theoretical discussion had taken place at all—as representative of a "European Socialism out of Christian responsibility" (Dirks 1946), quite similar to the German Christian Democrats. Embedded in the perception of the "Cold War" and caught up in the race for the votes of former National Socialists, the controversial term "Austrian nation", which was already breeding internal party antagonism by 1946, later faded away. Since Missong's "Austrian nation" was of a profoundly Catholic nature, it turned out to be a twofold obstacle in garnering support from the "formers". Symptomatically, then, before he was side-lined, he sought to attract the enormous potential of former "Greater German" voters by presenting "his" debate on the nation as the more neutral Reichsidee (imperial concept), and to transform the discourse on Austria into a debate on Europe (Missong 1949). The Austrian People's Party, however, replaced "Austrian nation" with the term Heimat (home, homeland). (Binder 2004).

Until 1989, the amalgamating terminology of Heimat was dominated by the backdrop of the "Cold War". In that context, Heimat was seen as a place under threat, a territory on the "blazing frontier" (Posch 1986), which, according to Hanns Koren, a Catholic bridge-builder and Styrian Austrian People's Party politician responsible for cultural affairs, had been entrusted with a perpetual function. "Ever since Styria has existed, Styrian people have always served both the smaller Heimat and the greater Reich [ ... ] Styrian history-how aptly Hans Kloepfer characterised it as 'a picture full of blood and wounds [ ... ] ]." With this metaphor from the Latin hymn Salve caput cruentatum (O Sacred Head, Now Wounded), Klöpfer, the poet who prepared the ground for National Socialism in Western Styria, sacralised Heimat by elevating it to the divinity of Christ. Koren continues further: "Known from time immemorial as the 'Frontier of the German Empire', it is a bitter title of honour for a vulnerable country that has always been open to the East and its avaricious predators on foot and horseback" (Koren 1966a). Koren, in a different passage, appeals to the young country folk: "Nobody should desert their Heimat [ ... ] Heimat is the only place on earth where there are people whom you can 
ultimately count on" (Koren 1966b). Koren, the Catholic bridge-builder, thus also appealed to the distinctive feelings of the German Nationalist elite who had defined their mission since the early 1950s as "Borderland Germans" struggling to defend the homeland against intruders (Weidinger 2015).

A phenomenon to which the German émigré historian Hans Rosenberg had explicitly referred had been crucial for the Christian Social milieu from the very beginning: uncertainty arising from modernity effected a reversion to pre-industrial social traditions (Rosenberg 1967), ranging from Karl Freiherr von Vogelsang and the papal encyclicals Rerum novarum (1891) and Quadrogesimo anno (1931) to Engelbert Dollfuss's speech at the Vienna Harness Racing Arena-a key document of Austrofascism - and the Austrian People's Party's views on gender and family. In that particular segment, Catholic and (German-) nationalist procreation strategists liaised both on the birth rate front and in the formatting of the Austrian Catholic Church laid down in the 1952 Maria Zell manifesto (Liebmann 2000a). Hence, the Heimat cult connected to it was intended to induce an antimodernist Volksgemeinschaft (people's community) as opposed to the social-democratic dominated city.

According to the Austrian People's Party manifesto of 1952, "the village is the most natural and healthiest form of settlement and a perpetual source of renewal of every people" (Berchtold 1966). The Maria Zell manifesto states further that "Austria possesses the sad reputation of having the world's lowest birth rate. We will soon become a nation of aged and starving beggars, for in a few decades, a whole generation of workers and producers will be missing. Nobody will be here to sow the grain to provide us with bread and nobody will mine the coal we need to warm ourselves, nor fell a tree to provide the planks for our final resting place" (Liebmann 2000b). Given this pessimistic outlook, then, it is not surprising that-from the viewpoint of the authors of the manifesto-the primary requirement was to call for state welfare for families and for "the social class that will sustain future generations, such as the Alpine peasantry" (Liebmann 2000b). Although the authors of the manifesto presented themselves as the mouthpiece of a united Catholic people, they sought to close ranks with the former National Socialists, offering them as a dowry the explicit demand for the end of a "certain absolutism of political parties and" of "special party legislation" (Liebmann 2000c). ${ }^{2}$

Both camps shared the concept of the "virile man" and the woman as "keeper of the holy hearth fire", even "if she", muses Hanns Koren, "may already cook on a propane gas hob or an electric cooker" (Koren 1966b). Franz Maria Kapfhammer, a genuine advocate of the Catholic Nationalists and Neuländer (Bund Neuland, founded in 1919 as a Christian-German student association), saw industrialised society as a potential threat to the family as a nucleus of the Heimat, since this form of society seemed to question "the political leadership" of the man as pater familias and "priest of the home" (Kapfhammer 1959). The father figure in question would only "find" his Heimat in the family when the woman as wife and mother acted as a "mediator" of male-connoted heavenly spheres, "which we characterise as the transcendental, supernatural and 'divine"', and "met" her central obligation as a child-bearer.

In a specific form of histoire de longue durée, the "people" were defined as an historical constant from which Heimat emerged: "The people [ ... ] is the population that lives on the land which is allotted to it by nature. [ ... ] The racial characteristics of the Danubian people, too, had long been constant at a time when those linguistic skills, which were stamped upon them through Romanisation, Germanisation and Slavicisation, were overestimated in the epoch of the concept of the Nation State and regarded as the sole criterion for determining the ethnic and national community of the peoples of the Danube region. In the course of history, several individual peoples have developed from the natural unity of this population. These are independent nations which belong to no other nation even if they speak the same language" (Österreichische Geschichte 1946). Taken from a teaching aid for training primary school teachers directly after World War II had ended in 1945, this is a model that

2 The explicit reference to denazification laws is only found in the longer version, but it should be noted that at this point in time the "lesser offenders" had already been exonerated from the consequences of their NSDAP party membership. Cf. (Liebmann 2000c). 
construed Heimat as a natural environment whose population was deeply rooted to the soil and "had always been there". ${ }^{3}$

In his reference to the staging of the 1946 Ostarrichi celebrations, which marked the 950th anniversary of the earliest recorded reference to the Margraviate of Austria, Ernst Bruckmüller points to the "primordial" effect of interweaving a historical document with current political requirements: "In 1946, one work was actually titled 'How Our Dear Lord Created AUSTRIA' (Frank and Wiegand 1946). This publication links the period of Creation with an outlook to the future, thus facilitating a connection between the demiurgic act of creating land and its later cultivation through mankind-in this case, the Austrians. Not one Austrian stereotype has been left out: mountains and lakes, the Arlberg tunnel, Tyrolese dumplings, the Grossglockner mountain, Salzburg, Carinthia, Styria, Peter Rosegger, the Steyr works, the Salzkammergut, Aggstein and Burgenland, finally, the Prater amusement park and a panorama of Vienna showing St. Stephen's Cathedral and, of course, Johann Strauss" (Bruckmüller 1995).

After 1945, Heimat perpetuated and forged identity on a "smaller" scale for all those who were not yet prepared to accept an Austrian nation without reservations. It is also worth mentioning that the Austrian Heimatfilm of the 1940s and 1950s, with its "metaphors relating to pre-industrial society", typically sported "patriarchal structures" as an antithesis to the "fluctuating masses" of modern urban life (Nierhaus 1966). In frequent references to the dual monarchy, all social conflict was transcended by the image of the benevolent Emperor. In the grip of the "Cold War", the Heimat narrative could also serve as a bulwark and provide a belated "Alpine fortress", while Austria was "neutralised" as a "bridge between East and West" and the "Heart of Europe" (Binder 2004). That kind of Heimat, to modify a quote from Thomas Bernhard, was leavened with a "Catholic-(German) national (socialist)" disposition (Lajarrige 2016).

The "Christian Heimat" and former Catholic "bulwark" has to be defended wherever it does not serve as a "bridge" between West and East or present itself as an "Island of the Blessed" created by dear God. That task was allotted to the Austrian Armed Forces set up in 1955/56.

From whence come the characteristic imperial vestiges that have arisen since 1955/56 and given the Austrian Armed Forces' traditions an anachronistic touch to the present day? It is the unresolved heritage of Austrofascist provenance reflected in the iconography of the Heldendenkmal (Heroes' Monument) at the Vienna Hofburg (Vereinigung zur Errichtung Eines Österreichischen Heldendenkmales 1934), for which Joseph August Lux, in commemoration of the monument's inauguration on 9 September 1934, delivered a political and historical narrative in his Goldenes Buch der Vaterländischen Geschichte, (Golden Book of Fatherland History) (Lux 1934).

The Heldendenkmal defined the canon of Austrian heroes by way of mere reference to names and battles, thus earmarking the Äusseres Burgtor as a "Temple of the Nation in its Eternal Struggle" and drawing on a tradition of "historical interpretation" that dates backs to Herodotus' portrayal of the "Greek Struggle for Freedom", in which one person is pinpointed as the "saviour" of the people against an overwhelming enemy.

Wallenstein heads the list of names. "According to the 'fatherland' perception of history" of Austrofascist provenance, "the positive end of the Thirty Years' War" for the Habsburg territories-'recatholisation, inner consolidation, assertion of absolutism'-was regarded as the "decisive step" required to "withstand the most formidable forthcoming conflict: the Turkish Wars" (Suppanz 1998). Taking care to stress the defensive character of Austria, the next name to follow Wallenstein on the monument is Ernst Rüdiger von Starhemberg (1638-1701) as "Defender of Vienna" in 1683, a central lieu de mémoire of Austrian mythology created in the "process of nation-building" (Bruckmüller 1998). In his critical analysis of the "Austrian heroic age", Ernst Brückmüller underscores the exaltation of the defence and relief of Vienna in 1683 in "fatherland" journalism that correlated

3 In 2009, the Swiss National Museum Zurich opened a new permanent exhibition on Swiss history, radically addressing that issue in a section called "No One Has Been Here All The Time”. Cf. (Andreas 2009). 
with the various facets of the political self-conception of individual groups at the close of the 19th century: "While German nationalist sentiment glorified the forces of the Holy Roman Empire of the German Nation, Catholic-universalist sentiment focused on the Poles, and Viennese local patriotism emphasized the heroic achievements of the citizens of Vienna" (Bruckmüller 1998, pp. 279-81), whose descendants were faithful Christian Social voters. In terms of this ambiguity, Count Starhemberg could be compared to the Capuchin Marco d'Aviano, whom the apologetics of those years elevated to a central shining figure. ${ }^{4}$ Starting with the 1883 celebrations of the 200th anniversary of the Battle of Vienna, the latter, as a confidant of Emperor Leopold I, experienced a tremendous renaissance in staunch Catholic-conservative circles until 1938 (Press 1960). However, his veneration was discontinued after $1945,{ }^{5}$ since, in an apologetic sense, it put d'Aviano on an equal level with Engelbert Dollfuss, thus creating a barrier to former German Nationalist voters (Suppanz 1998, p. 171). The defeat of Ottoman forces at the gates of Vienna, a historical flashpoint marking their subsequent retreat to south-eastern Europe, tilted the fear of the "heathen" enemy in contemporary propaganda into "the questionable legitimation of a Crusade for Christianity", in order to "wage a ruthless war of destruction in which taking prisoners remained an exception".

From 1933 on, efforts to cultivate "Austria" concentrated on the menace to the "Christian West" posed by the "advance" of the "Ottoman Empire", which was compared to the same threat posed by "heathen" National Socialism and, in a fanciful analogy to Hitler's failure through Engelbert Dollfuss's "martyrdom", the "demise of European Turkey (1683-1913)" (Schier 1935) that started with the relief of Vienna (Dreidemy 2014). Both failed, as it were, due to "the Christian, Catholic" bulwark of Vienna. Werner Suppanz has explicitly noted how intensely the authoritarian corporate state's "Austrian ideology" exploited the "Turkish Wars" in order to gain political legitimation from that analogy (Suppanz 1998, pp. 156-62). During the Cold War, the Soviet Union, whose Communist imperialism posed a threat to free Europe, took over the enemy motif from the Nazis, thus again reinstating Austria in her role as a "Christian bulwark".

Diffuse memories of the "Turkish menace" instilled in primary school children during Heimatkunde (local history and culture) lessons served as an expedient and long-lasting frame narrative for the country's current positioning in the "Cold War". As late as 1986, this Heimat, embracing a historical-political pseudo-geographical narrative stretching from the Neolithic Age to 1945, was extolled as a "sedentary and dense culture" and "defensively organised" in character, in stark contrast to the "invading nomads, cattle drovers and horse people(s) from the Pannonian steppe", with their completely different, attack-based strategies, that always appeared when "they lost their grasslands to the more powerful-in accordance with the relentless law of the ,Steppe', when they conduct extensive raids or are propelled by world domination ideologies" (Pferschy 1986).

Henceforth, Frederick II, the "godless" Prussian, who would become a precursor of Adolf Hitler, replaced the "heathen Turks" in the incantation of the Heldendenkmal. Maria Theresia, a "sister" of the Maria Zell Magna Mater Austriae, was forced to contend with the "most unchivalrous and predacious of opponents" for "the Austrian homelands" (Lux 1934, p. 260). Essentially, the "chivalrous enthusiasm" amongst Hungarian magnates at the Pressburg Reichstag in 1741, who vowed the sacrifice of "blood and life"-vitam et sanguinam — to the young mother seeking their help (Lux 1934, p. 260), was popularised in the 19th century dynastic narrative of the Habsburg empire through historical portraiture (Bruckmüller 1998, 284f). This noble knighthood stood at the head of the fight against Frederick II who would not hesitate to "set fire to Europe and take what he wants in the process".

Enlightenment and French Revolution created the purgatory out of which Austria emerged as an empire and sacred "bulwark of Catholic culture" in a new "heroic age". Hence, a political-military

4 Kalender der Vaterländischen Front 1935, 140, cited in (Suppanz 1998, p. 171).

5 One last attempt in this milieu was undertaken by Vincenzo Crisculo in his essay titled "Markus von Aviano. Christophorus und Retter Europas", which appeared in Jan Mikrut's publication "Faszinierende Gestalten der Kirche Österreichs". Cf. (Crisculo 2000). 
threat was again interpreted as a religious war, dubbing Napoleon as the "antichrist", and as a revenant of the "godless and dishonourable" Frederick, who was followed by Adolf Hitler in the memorial's initial period, paving the way for the Cold War's menacing anti-Communist scenario.

In 1934, Radetzky's naming amongst the "commanders of the armed forces" stood for 1848/49 and for the crushing of the revolution (Rauchensteiner 2003). It represented a reactionary political mindset that had always stood up against liberal ideas (Allmayer-Beck 1983). The "Golden Book of Fatherland History" reflects this aspect of 1848/49 in the light of the National Socialists' "national revolution" and the "corporative" regime's renunciation of democracy, whereby Lux, evidently unable to contain his agitation, asserts that "freedom and nation" had been the catchwords of the French Revolution during the 1848 revolution, too: a dual goal that despite being somewhat ambivalent, was all the more intoxicating. "[ ... ] The masses did not know what it was all about; they never do. [ ... ] Nonetheless, a vague urge in which lay the quasi justified demand for a charter. 'Constitution' was the magic word of the day. Parliamentary representation of the people shaped on the English model, but re-shaped on the French one-freed of all fetters, economically, politically, religious. Liberalism. [ ... ] The other course of direction is driven by the desire for national independency. [ . . ] Liberalism, party and controlling interest, Freemasonry embellished with bards' beards and plenty of freedom song-singing. [ ... ] Liberalism always leads to radicalism via nationalism" (Lux 1934, p. 301f).

To put it succinctly: embedded in the celebrations commemorating the "liberation from the Turks" within the frame of the Catholics' Day, Engelbert Dollfuss, at the first general roll call of the "Fatherland Front" on 11th September 1933 at the Vienna Harness Racing Arena, maintained that "despotism" would surely follow "Liberalism" (Dollfuß 1966). His government, though, had ended "the era of Marxist, materialist demagogy" and would fight against "synchronisation and terror" by way of "authority". This "authority" arose from "leadership through responsible and selfless men who were prepared to make sacrifices", who, like "Christian-Catholic" officers fighting on the front, were "fulfilling nothing less" than their "duty" (Dollfuß 1966, p. 430). Radetzky, therefore, stood for authority, and for the fight against liberalism and nationalism.

With Franz Conrad von Hötzendorf (1852-1925) (Binder 2014) the Heldendenkmal served a heroic cult that drew in equal measure from 19th century Catholic-Conservative and German National bourgeois circles (Binder 2016). Lawrence Sondhaus characterises Conrad as an "architect of the Apocalypse" (Sondhaus 2000). When Emperor and King Charles I dismissed Conrad as Chief of Staff in early 1917, some 7.5 million k.u.k. (imperial and royal) soldiers had been on active service, 700,000 of whom had fallen, 600,000 rendered unfit for service and 1,500,000 captured. In his various recriminations, Conrad himself speculated about stab-in-the-back legends: it had been "Austria-Hungary's mistake to allow Serbian evil to ripen to a magnitude that it had already had in 1914" that could only be the machinations of "subversive forces in the interior", which he finally claimed to have identified: "Czechs, Italians, Poles, Romanians, Serbs, Magyars, the Sokol movement and School Associations, etc., clergy, agitators, the press, Social Democrats, hostility towards the army in Bohemia and nationalist currents in the army" (Von Hötzendorf 1977). Conrad, finally interpreting defeat as a loss of old Frankish chivalry due to modernity, concluded: "We conducted war according to established tradition, whereas our adversaries came up with all the tricks of modern knavery" (Von Hötzendorf 1977, p. 111).

Conrad's anti-democratic stance, his modernisation phobia, racism, crude Darwinism and talk of "a struggle for survival governed by laws inconceivable" (Von Hötzendorf 1977, p. 79) created the breeding ground for growing revisionism, fascism and National Socialism after 1918. His adherence to the camaraderie of the "old Army", his espousal of Obsorge (caring for his soldiers) and gratitude "towards the army and brave officers who for four long years fought for Emperor and Empire" (Von Hötzendorf 1977, p. 121) cited the "generation of front fighters" whose figurehead, Engelbert Dollfuss, was celebrated before, and especially after, his death in 1934 . From 1945 on, Conrad was regarded as the last "knight", and, as such, he was largely in step with the heroic cult that had emerged in the course of bourgeois self-ennoblement in the late 19th century, thus delivering the political "glue" 
needed by the Austrian People's Party to court former National Socialists as of 1948/49. His drivel about the "preventive strike" whitewashed Austria-Hungary's responsibility for the outbreak of the War in 1914 and provided the backdrop for the "formers" to at least legitimise the invasion of the Soviet Union.

From 1956 on, Pietas Austriaca, in its deeply-rooted Catholicism, was placed in an ecumenical context. Not so much, however, to satisfy theological requirements, but rather to garner the support of German Nationalist clientele. In the Los-von-Rom-Bewegung (Away From Rome movement) of the late 19th century, German Nationalists, with their catchphrase "to be German means to be Lutheran!", had attacked the Catholic self-conception of the Christian Socials and amalgamated völkisch borderland activity with Lutheran evangelisation and National Socialist infiltration in the settlement policy of new "Reich German" settlers, who had moved, for example, to Carinthia in the interwar years, propagandistically criticising the authoritarian "corporative state" as a new "Counter Reformation". The ecclesiastical prop men of rapprochement, who in 1935 had defined the Catholic Action as a "heavenly Fatherland Front", now volunteered to act as a cross-camp "people's community". They set the stage by digging out familiar trimmings. At the 1950 Styrian Catholics' Day-the first after the end of the war-they opened the event with bonfires on the hills and a torchlight procession. The young marchers, wearing white socks and white shirts to match their short leather trousers (Lederhosen), carried the statuette of Our Lady of Maria Zell from there to Graz to inaugurate the event, thus consummating the "recatholisation" of the former Nazi "City of the Popular Uprising" ("Stadt der Volkserhebung").

During the 1950s and 1960s, the strictly Catholic Pietas Austriaca was modified under the aegis of "Ecumenism" to form an apodictically accepted "Christian" Austria, thus ignoring the process of secularisation central to modernity. The 1951 procession accompanying the newly cast great bell of St. Stephen's Cathedral, the Pummerin, from Linz to Graz could be characterised as symptomatic of that trend. At the end of that development, and embedded in the collapse of the bipolar world in 1989/90, various prominent political leaders, for instance Social Democratic politician and mayor of Vienna Helmut Zilk, collected money for the restoration of Pietas Austriaca's edificial remains, such as St. Stephen's Cathedral in Vienna and the Basilica of Maria Zell. At almost the same time, Pope John Paul II beatified Emperor and King Charles I, the last representative of Pietas Austriaca of Habsburg provenance. Efforts to that effect had already commenced shortly after Charles' death in 1922. However, the complete historicisation of that person largely purged his beatification of all political controversy.

Austrian identity grew parallel to her gross domestic product, and participation in the Western European economic miracle became a major factor for the acceptance of an "Austrian nation" (Bruckmüller 1994). The end of the Cold War and accession to the European Union finally created room for Heimat/en. At the same time, certain people associated with the Freedom Party of Austria (Freiheitliche Partei Österreichs, FPÖ), who still regarded "Austrian identity" as problematic, crept to the fore, voicing their opinions anything but quietly. In a feeble attempt to overcome their minority position, they claim that the Heimat is threatened anew through Umvolkung, ethnic conversion of those believed to have lived there since distant times. By evoking the "Christian bulwark" and raising the crucifix, alongside clumsy alliterations in election posters, they seek to rekindle the grossly overused image of Vienna in the year of 1683 . That this could now become the speciality of a basically secular party that is sceptical towards political Catholicism is the outcome of societal secularisation mentioned earlier, even though the far right reactionary wing of active Catholicism, now shrunk to a thin sliver gathered around auxiliary bishop Andreas Laun-who presents himself as a revenant of Marco d'Aviano-joins in vociferously. It would seem that the Freedom Party of Austria has ultimately become the sublessee of Pietas Austriaca.

Conflicts of Interest: The author declares no conflict of interest. 


\section{References}

Allmayer-Beck, Johann Christoph. 1983. Johann Josef Wenzel Graf Radetzky von Radetz. In Österreichisches Biographisches Lexikon. Vienna: Akademie der Wissenschaften, vol. 8, p. 370f.

Bauer, Otto, ed. 1934. Der Aufstand der österreichischen Arbeiter. Seine Ursachen und seine Wirkungen. Prague: Verlag der Deutschen Sozialdemokratischen Arbeiterpartei in der Tschechoslowakischen Republik. In Werkausgabe. Vienna: Europaverlag, vol. 3, p. 970.

Berchtold, Klaus, ed. 1966. "Alles für Österreich", programmatische Grundsätze der Österreichischen Volkspartei, 1952. In Österreichische Parteiprogramme 1868-1966. Vienna: Verlag für Geschichte und Politik, p. 379.

Binder, Dieter A. 2004. "Rescuing the Occident" and "Europe in Us": The People's Party in Austria. In Christian Democracy in Europe since 1945. Edited by Michael Gehler and Wolfram Kaiser. London and New York: Routledge, vol. 2, pp. 139-54.

Binder, Dieter A. 2008. Fresko in Schwarz? Das christlichsoziale Lager. In ... der Rest ist Österreich. Das Werden der Ersten Republik. Edited by Helmut Konrad and Wolfgang Maderthaner. Vienna: Carl Gerold's Sohn, vol. 1, pp. 241-60.

Binder, Dieter A. 2014. Conrad von Hötzendorf revisited. In Der verhängnisvolle Irrtum. Zur Analyse von Fehlleistungen in Politisch-Militärischen Kontexten. Edited by Harald Heppner. Berlin: Duncker \& Humblot, pp. 83-96.

Binder, Dieter A. 2016. Helden. In Habsburg neu Denken. Vielfalt und Ambivalenz in Zentraleuropa. 30 Kulturwissenschaftliche Stichworte. Edited by Johannes Feichtinger and Heidemarie Uhl. Vienna, Cologne and Weimar: Böhlau, pp. 82-88.

Bruckmüller, Ernst. 1984. Nation Österreich. Sozialhistorische Aspekte ihrer Entwicklung. Vienna, Cologne and Graz: Böhlau, p. $156 f$.

Bruckmüller, Ernst. 1994. Österreichbewußtsein im Wandel. Identität und Selbstverständnis in Den 90er Jahren. Schriftenreihe des Zentrums für Angewandte Politikforschung 4; Vienna: Signum.

Bruckmüller, Ernst. 1995. Millennium!-Millennium? In Österreich in Geschichte und Literatur. Wien: Braumueller, vol. 38, p. 140.

Bruckmüller, Ernst. 1998. Österreich, An Ehren und Siegen reich. In Mythen der Nationen: Ein europäisches Panorama. Edited by Monika Flacke. Munich and Berlin: Koehler \& Amelang, pp. 269-94.

Crisculo, Vincenzo. 2000. Markus von Aviano. Christophorus und Retter Europas. In Faszinierende Gestalten der Kirche Österreichs. Edited by Jan Mikrut. Vienna: Dom, vol. 1, pp. 11-34.

Dirks, Walter. 1946. Die zweite Republik. In Frankfurter Hefte. Frankfurt/M.: Frankfurter Hefte, vol. 1, p. 22.

Dollfuß, Engelbert. 1966. Die “Trabrennplatz-Rede". In Österreichische Parteiprogramme 1868-1966. Edited by Klaus Berchtold. Vienna: Verlag für Geschichte und Politik, pp. 427-33.

Dreidemy, Lucile. 2014. Der Dollfuß-Mythos. Eine Biographie des Posthumen. Vienna, Cologne and Weimar: Böhlau. Frank, Marga, and Johannes Peter Wiegand. 1946. Wie der liebe Gott Österreich Erschaffen Hat. Vienna: Alexa.

Friedrich Gustav Cardinal Piffl. 1992. Brief. In Republik Österreich 1918-1938. Edited by Walter Goldinger and Dieter A. Binder. Vienna: Verlag für Geschichte und Politik, p. 24f.

Kapfhammer, Franz Maria. 1959. Familie und Heim. In Die Heimat lädt dich ein. Eine Gabe an die Steirischen Jungbürger. Edited by the Landesjugendreferat der Steiermärkischen Landesregierung. Graz: Landesjugendreferat, p. 27.

Klahr, Alfred. 1937. (Published under the pseudonym "Rudolf"). Zur nationalen Frage in Österreich. Weg und Ziel 3/4: 126-33, 173-81.

Koren, Hanns. 1966a. Die Steiermark—Einheit und Eigenart des Landes. In Reden. Edited by Hanns Koren. Graz: Steirisches Volksbildungswerk, p. 200f.

Koren, Hanns. 1966b. Euch ist das Schicksal des Landes in die Hand gegeben. In Reden. Edited by Hanns Koren. Graz: Steirisches Volksbildungswerk, p. 264f.

Lajarrige, Jacques. 2016. Die Leiche im Keller. Les écrivains face au passé nazi de l'Autriche. In Le Travail de Retour Sur le Passé à L'époque de la Seconde République Autrichienne. Edited by Anne-Marie Corbin and Marc Lacheny. Mont, Saint and Aignan: PURH (Austriaca. Cahiers Universitaires D'information sur l'Autriche 82), pp. 29-50.

Liebmann, Maximilian. 2000a. Das "Mariazeller Manifest" als Teil einer Doppelstrategie. In Brennpunkt Mitteleuropa. Edited by Ulfried Burz, Michael Dendarsky and Werner Drobesch. Klagenfurt: Carinthia, pp. 639-97.

Liebmann, Maximilian. 2000b. Mariazeller Manifest, (Abridged Version). Klagenfurt: Carinthia, pp. 650-53.

Liebmann, Maximilian. 2000c. Mariazeller Manifest (longer version). Klagenfurt: Carinthia, pp. 653-56. 
Liebmann, Maximilian. 2003. Von der Dominanz der katholischen Kirche zur freien Kirche im freien Staat. In Geschichte des Christentums in Österreich. Von der Spätantike bis zur Gegenwart. Edited by Rudolf Leeb, Maximilian Liebmann, Georg Scheibelreiter and Peter G. Tropper. Vienna: Ueberreuter, pp. 361-456.

Lux, Joseph August. 1934. Das Goldene Buch der Vaterländischen Geschichte für Volk und Jugend Österreichs. Vienna: Gerlach \& Wiedling, pp. 191-272.

Missong, Alfred. 1949. Sinn- und Formwandel der Reichsidee. In Österreichische Monatshefte. Reprinted in Christentum. Vienna, Cologne and Graz: Böhlau, pp. 213-25.

Missong, Alfred. 2006. Alfred Missong-Der Entdecker der Österreichischen Nation. In Christentum und Politik. Ausgewählte Schriften 1924-1950. Edited by Alfred Missong. Vienna, Cologne and Graz: Böhlau, pp. 47-56.

Mutschlechner, Martin. n.d. Pietas Austriaca. Die Welt der Habsburger. Available online: http:/ /www.habsburger. net/de/themen/pietas-austriaca?language=en (accessed on 1 May 2017).

Nierhaus, Irene. 1966. Heimat und Serie. Zum Wohnbau nach 1945. In Inventur 45/55. Österreich im Ersten Jahrzehnt der Zweiten Republik. Edited by Wolfgang Kos and Georg Rigele. Vienna: Sonderzahl, pp. 329-44.

Österreichische Geschichte. 1946. Hectographed Manuscript for the 1945/46 School Year at Graz Teachers' Training College, Courtesy of Frau Dr. Christa Höller, Graz. First published 1945.

Pferschy, Gerhard. 1986. Grenzfunktionen des steirischen Raumes. In Die Steiermark. Brücke und Bollwerk. Graz: Landesarchiv, pp. 1-7.

Posch, Fritz. 1986. Flammende Grenze. Die Steiermark in den Kuruzzenstürmen, 1st ed. Styria: Graz, Vienna and Cologne.

Press, Volker. 1960. Marco d'Aviano. In Neue Deutsche Biographie. München: Akademie der Wissenschaften, vol. 16, p. 128f. Available online: http:/ / www.deutsche-biographie.de/pnd118731076.html (accessed on 12 February 2016).

Rauchensteiner, Manfried. 2003. Johann Josef Wenzel Anton Franz Karl Graf Radetzky de Radetz. Neue Deutsche Biographie. Available online: http://www.deutsche-biographie.de/pnd118597647.html (accessed on 16 February 2016).

Reich, Walter. 2000. Die Ostmärkischen Sturmscharen. Frankfurt: Lang.

Rosenberg, Hans. 1967. Depression und Bismarckzeit. Wirtschaftsablauf, Gesellschaft und Politik in Mitteleuropa. Berlin: De Gruyter, p. 242.

Schier, Wilhelm. 1935. Atlas zur Allgemeinen und Österreichischen Geschichte. Vienna: Hölder-Pichler-Tempsky.

Sondhaus, Lawrence. 2000. Franz Conrad von Hötzendorf: Architect of the Apocalypse. Boston: Humanities Press.

Spillmann, Andreas, ed. 2009. Geschichte Schweiz. Katalog der Dauerausstellung im Landesmuseum Zürich. Zurich: Schweizerisches Landesmuseum, p. 20.

Staudinger, Anton, Wolfgang C. Müller, and Barbara Steininger. 1995. Die Christlichsoziale Partei. In Handbuch des Politischen Systems Österreichs. Erste Republik. Edited by Emmerich Tálos, Herbert Dachs and Ernst Hanisch. Vienna: Manz, pp. 160-76.

Suppanz, Werner. 1998. Österreichische Geschichtsbilder. Historische Legitimationen in Ständestaat und Zweiter Republik. Cologne, Weimar and Vienna: Böhlau, p. 156.

Vereinigung zur Errichtung Eines Österreichischen Heldendenkmales, ed. 1934. Gedenkschrift Anläßlich der Weihe des Österreichischen Heldendenkmales a.m. 9. September 1934. Vienna: Selbstverlag.

Von Hötzendorf, Franz Conrad. 1977. Private Aufzeichnungen. Edited by Kurt Peball. Munich: Amalthea, p. 91.

Weidinger, Bernhard. 2015. "Im nationalen Abwehrkampf der Grenzlanddeutschen". Akademische Burschenschaften und Politik in Österreich Nach 1945. Vienna, Cologne and Weimar: Böhlau.

Winter, Ernst Karl, August Maria Knoll, Alfred Missong, Wilhelm Schmid, and Hans Karl Freiherr von Zeßner-Spitzenberg. 1927. Die Österreichische Aktion. Vienna: Reinhold.

Wohnout, Helmut. 2004. Middle-Class Governmental Party and Secular Arm of the Catholic Church: The Christian Socials in Austria. In Political Catholicism in Europe 1918-45. Edited by Wolfram Kaiser and Helmut Wohnout. London and New York: Routledge, vol. 1, pp. 172-94.

(C) 2017 by the author. Licensee MDPI, Basel, Switzerland. This article is an open access article distributed under the terms and conditions of the Creative Commons Attribution (CC BY) license (http:/ / creativecommons.org/licenses/by/4.0/). 